\title{
DISCRIMINATORY CUSTOMARY PRACTICES AGAINST WOMEN'S RIGHTS: AN ACCOUNT OF INTERVENTION STRATEGIES BY SOUTHERN AFRICAN DEVELOPING STATES
}

\author{
Grace Agonda Akolokwu* \\ Barakat Adebisi Raji**
}

\begin{abstract}
Discriminatory customary practices against the protection of gender rights still thrive in many Southern African developing states despite domestic and international legal regimes to prevent them. These practices were borne out of customary inclinations of the patriarchal social system in most African communities, which hold women and the girl-child in perpetual subordination to the male. In other words, the African customary systems wrongly perceive the male gender as being naturally superior to the female. More so, the loopholes in the executive and legislative efforts to combat human rights abuses as well as judicial pronouncements and governmental apathy in eradicating abuses against gender discrimination towards women in the Southern African Developing States are apparent. Consequently, discriminatory customary practices continue to thrive despite legislative framework protecting gender rights in the states. The methodology adopted in this paper is a doctrinal approach, which places reliance on legal materials that are enacted and enforced by African Developing states. The article examines international and states laws, norms, institutions, international and national publications and other international legal instruments relating to gender discrimination. Most importantly, the central attention of this study focuses on the discriminatory customary practices against women in the Southern African Developing States. The current study finds that, despite
\end{abstract}

LL.B, BL, LLM and PhD, Senior lecturer, Department of Private and Property Law, Rivers State University, Nkpolu-Oroworukwo, Port Harcourt. Email: akolokwu.grace@gmail.com.

** LL.B, BL, LL.M and PhD (IIUM), A Lecturer in the Department of Jurisprudence and International Law, Faculty of La, University of Ilorin, Ilorin, Nigeria; E-Mail: babraj2007@gmail.com or raji.ba@unilorin.edu.ng 
identifiable discriminatory customary practices which are still practised and condoned as being the lifestyle and tradition of groups are criminalized and declared abhorrent by specific domestic legislation of nations, the human rights of the girl-child and women continue to be in chains and fetters. In conclusion, this article advocates increased advocacy, judicial activism and more proactive legislative action that protect women and the girl-child in the Southern African developing states.

Keywords: customary law, gender rights violations, Southern African Development Community (SADC) States, Kenya, Nigeria

\title{
AMALAN-AMALAN ADAT YANG MENDISKRIMINASI HAK-HAK GENDER: PENERANGAN MENGENAI PELBAGAI STRATEGI CAMPURTANGAN OLEH NEGARA- NEGARA MEMBANGUN AFRIKA SELATAN
}

\begin{abstract}
ABSTRAK
Amalan adat yang mendiskriminasikan hak gender masih berlaku di kebanyakan negara-negara membangun di Afrika Selatan walaupun regim undang-undang domestik dan antarabangsa menghalangnya. Amalan-amalan ini dizahirkan oleh kecenderungan adat sistem sosial patriarki dalam kebanyakan masyarakat Afrika yang menganggap wanita dan anak perempuan sebagai lebih rendah daripada lelaki. Dalam erti kata lain, sistem adat Afrika telah menyalah anggap bahawa lelaki secara semula jadi adalah lebih mulia daripada wanita. Keadaan ini bertambah buruk apabila terdapat kelemahan dalam usaha eksekutif dan perundangan untuk memerangi pencabulan hak asasi manusia serta keputusan kehakiman yang berat sebelah dan sikap tidak peduli kerajaan dalam membanteras diskriminasi gender terhadap wanita di negara-negara membangun Afrika Selatan. Akibatnya, amalan adat yang mendiskriminasikan wanita terus berkembang walaupun terdapat rangka kerja perundangan yang cuba melindungi hak gender. Metodologi yang diterapkan dalam makalah ini adalah pendekatan doktrinal yang berdasarkan kepada sumber undang-undang yang dibuat dan dikuatkuasakan oleh negara-negara membangun di Afrika. Makalah ini mengkaji undang-undang negara dan antarabangsa, norma, institusi, penerbitan nasional dan antarabangsa serta
\end{abstract}


instrumen undang-undang antarabangsa lain yang berkaitan dengan diskriminasi gender. Yang paling penting, kajian ini memberi tumpuan kepada amalan adat yang mendiskriminasi wanita di negara-negara membangun di Afrika Selatan. Hasil kajian mendapati bahawa, walaupun amalan adat diskriminasi yang dikenal pasti yang masih diamalkan sebagai gaya hidup dan tradisi kumpulan telah dikritik dan diisytiharkan sebagai kejam oleh undang-undang tempatan, hak asasi anak perempuan dan wanita masih terbelenggu. Sebagai kesimpulan, makalah ini menyokong peningkatan advokasi, aktivis kehakiman dan tindakan perundangan yang lebih proaktif bagi mengatasi masalah amalan adat yang mendiskriminasi wanita dan anak perempuan di negara-negara membangun Afrika Selatan.

Kata kunci: Undang-undang adat, hak-hak gender, pencabulan, negara-negara Southern African Development Community (SADC), Kenya, Nigeria.

\section{INTRODUCTION}

Gender issues are both localized and global. This can be seen in the continuous interference of particular customs and traditions peculiar to a group of people into the lives of women, especially in the area of human rights. ${ }^{1}$ Despite these local interferences through customary laws, it is trite that human rights are universal and inalienable for every member of the human family principally because of their humanness.

The patriarchal system usually promoted by various customary laws emphasizes descent along the father's line and this has worsened the fate of the women who are conditioned by the society to play a second fiddle

\footnotetext{
${ }^{1}$ Mikateko Joyce Maluleke, "Culture, Tradition, Custom, Law and Gender Equality," Potchefstroom Electronic Law Journal/PotchefstroomseElektronieseRegsblad 15, no. 1 (2012); John Cantius Mubangizi, "A South African Perspective on the Clash between Culture and Human Rights, with Particular Reference to Gender-Related Cultural Practices and Traditions," Journal of International Women's Studies 13, no. 3 (2012): 33-48; Anne Hellum, "Women as Subjects in the Process of Law: The Use of Empirical Sources in Women's Law," Occasional Paper 18 (2014): 176-193.
} 
role to the male. ${ }^{2}$ With an assured traditional role in the kitchen, which does not require the expertise garnered from any kind of education, the sentiments that the girl-child does not need to go to school to become a good wife and mother, with cooking, cleaning and sewing skills have persisted in the $21^{\text {st }}$ century. This confirms the notion that "women have always been discriminated against and have suffered and are suffering discrimination in silence in the hands of their men." ${ }^{3}$ This was the position of the court in Mahdu Kishwar v State of Bihar. ${ }^{4}$ These discriminations have been described as:

${ }^{2}$ Philomena Yeboah, “Trials of Motherhood: Amma Darko's Portrayal of Conflicts in Mother-Daughter Bonds in Her Novels: Beyond the Horizon, The Housemaid, Faceless and Not without Flowers," (PhD diss., Kwame Nkrumah University of Science and Technology, Kumasi, 2015), 158-182. See also Edward M. Akita, "Hegemony, Patriarchy and Human Rights: The Representation of Ghanaian Women in Politics," (PhD diss., Ohio University, 2010), 211.

${ }^{3}$ Lorretta F. C. Ntoimo and UcheIsiugo-Abanihe, "Patriarchy and Singlehood among Women in Lagos, Nigeria," Journal of Family Issues, published online (November, 21, 2013): 2-31; M.G. Techane, "Economic Equality and Female Marginalisation in the SDGs Era: Reflections on Economic Rights of Women in Africa," Peace Human Rights Governance, 1(3), (2017): 333-364; I. Sharma, "Violence against women: Where are the solutions?" Indian journal of psychiatry, 57(2), (2015):131; P.G. Kumari, et al., "Wake up Call to Halt the Evolving Epidemic of Sexual Offence in India: Urgent Need to Find out the Solutions," Panacea Journal of Medical Sciences, 6(1), (2016): 3-7.

${ }^{4}$ Mahdu Kishwar v State of Bihar (1996 5 SCC 125); T. M. Karjala, "Sixty Years of Silence: Gender Discrimination under International Refugee Law, (PhD diss., Stellenbosch University, 2016). See also Smart L. Richman, \& M. R. Leary, "Reactions to Discrimination, Stigmatization, Ostracism, and other Forms of Interpersonal Rejection: A Multimotive Model," Psychological Review, 116(2), (2009): 36594-106; J. L. Martorell, and M. A. Carrasco, "Review of Parental Acceptance-Rejection: Measures and Related Constructs [Special issue]," AcciónPsicológica 11, no. 2 (2014). See also Poonam Puniaand Sandeep Berwal, "Development and Standardization of an Alienation Scale for Visually Impaired Students," Journal of Visual Impairment \& Blindness 111, no. 5 (2017): 427-439. 
"Any distinction, exclusion or restriction made on the basis of sex which has the effect or purpose of impairing or nullifying the recognition, enjoyment or exercise by women."5

Gender issues have become a recurrent phenomenon due to the nonrecognition of women's rights and the persistence of the marginalization of women. ${ }^{6}$ The intensification of rights of women has led to feminism movement all over the world. This has been translated and reflected in

${ }^{5} \mathrm{M}$ Rao, Law Relating to Women and Children, 3rd ed. (Lucknow: Eastern Book Company, 2012): 62; D. Azuh, M. D. Egharevba, \& A. E. Azuh, "Gender Discrimination and National Politics: The Nigerian Case," Covenant University Journal of Politics and International Affairs, 2(2), (2016):1-12; I. S. Emakhu, "The Nature and Prevalence of Violence against Women in Nigeria," European Scientific Journal, ESJ, 9(19), (2013): 1-10; R. Steyn, \& L. Jackson, "GenderBased Discrimination in South Africa: A Quantitative Analysis of Fairness of Remuneration. South African journal of Economic and Management Sciences, 18(2), (2015):190-205; A. M. Adelekan, \& M. H. Bussin, "Gender Pay Gap in Salary Bands among Employees in the Formal Sector of South Africa," SA Journal of Human Resource Management, 16(1), (2018):1-10. . ${ }^{6}$ Adefolake O. Ademuson, "Women Domination and Oppression in Nigerian Society: Implications for Sustainable Development," African Journal for the Psychological Studies of Social Issues 19, no. 1 (2016): 24-36; Makama, Godiya Allanana, "Patriarchy and Gender Inequality in Nigeria: the Way Forward," European Scientific Journal, ESJ9, no. 17 (2013): 1-30; Ekpe at al., "Women Gender Equality in Nigeria: A Critical Analysis of Socio-Economic and Political (Gender Issues)," Journal Research in Peace Gender and Development 4, no. 1 (2014): 15-20; Felipe Jaramillo Ruíz, "Power, Gender and Democracy: From Domination to Gender Equality," RevistaCientífica General José María Córdova 11, no. 12 (2013): 107-125; M.G. Techane and Joanna Whiteman, "Tackling Socio-Economic Disadvantage: Making Rights Work," The Equal Rights Review 12 (2014): 95-108; Chabaya, et al, "The Persistence of Gender Inequality in Zimbabwe: Factors that Impede the Advancement of Women into Leadership Positions in Primary Schools," South African Journal of Education 29, no. 2 (2009): 1-18; Sylvia Ifemeje and IkpezeOgugua, "Global Trend Towards Gender Equality: Nigeria's Experience in Focus," Kuwait Chapter of Arabian Journal of Business and Management Review 33, no. 852 (2012): 1-13. 
the various Conventions passed by the United Nations. ${ }^{7}$ This has also been corroborated in the work of Bunch who mentions:

"Human rights instruments and mechanisms provide avenues for challenging the systematic abuse of women; and that government can be made to take gender-based violations more seriously." 8

This is the more reason why the issues of equality and freedom of women remain topical as aptly summed up by Janet. ${ }^{9}$

Equality is not only an independent autonomous right guaranteed in all national and international legal systems but it is also an inherent element of all human rights documents. Human rights do not make sense when they do not include entitlements for all human beings. In this way, equality is closely related to the universality of the right as asserted

${ }^{7}$ C. Buchanan et al., "From Clause to Effect: Including Women's Rights and Gender in Peace Agreements," Center for Humanitarian Dialogue: Geneva, (2012): 1-13; T. Agrawal, "Occupational Segregation in the Indian labour market. The European Journal of Development Research, 28 (2), (2016): 330351, T. Agrawal, \& A. Agrawal, "Trends in Occupational Gender Segregation in India," International Journal of Gender Studies in Developing Societies, 1(1), (2015): 4-24.

${ }^{8}$ Mary Manandhar et al., "Gender, Health and the 2030 Agenda For Sustainable Development," Bulletin of the World Health Organization 96, no. 9 (2018): 644; R. Dhatt et al., "The Role of Women's Leadership and Gender Equity in Leadership and Health System Strengthening," Global Health, Epidemiology and Genomics 2 (2017). 26; R. Manjoo, \& C. McRaith, "Gender-Based Violence and Justice in Conflict and Post-Conflict Areas," Cornell Int'l LJ, 44, 11 (2011); Catherine Hawkins, "Women's Human Rights: The Global Intersection of Gender Equality, Sexual and Reproductive Justice, and Healthcare," Journal of Research on Women and Gender 4, (March - 2012):1-26.

${ }^{9}$ Fleur Van Leeuwen, "Milestone or Stillbirth? An Analysis of the First Judgment of the European Court of Human Rights on Home Birth," Equality and Human Rights: Nothing but Trouble? (2015): 197; Janet RadcliffeRichards, "Only X\%: The Problem of Sex Equality,"Journal of Practical Ethics 2, no.1 (2014): 24. See also E. Kidd White, "There is no such thing as a right to human dignity: A reply to Conor O'Mahony," International Journal of Constitutional Law 10, no. 2 (2012): 575-584; Paolo G. Carozza, "Human Dignity and Judicial Interpretation of Human Rights: A reply," European Journal of International Law 19, no. 5 (2008): 931-944. 
by Van den Brink, et al.. ${ }^{10}$ This is to say that the rights of women have not been given proper attention despite all the legal instruments put in place to eliminate the discrimination phenomenon existing between them and their male counterparts.

While adopting a doctrinal research methodology, this article interrogates the discriminatory customary practices on gender rights and looks at the various states' intervention strategies that are happening in Southern African developing states. For the purpose of the study, the countries of Nigeria and Kenya are selected for a comparative analysis because these countries are Third World countries bogged with issues of poverty and diseases. They also have the history of great interplay of customary and statutory law.

\section{GENDER RIGHTS}

Gender rights concerns aspects of human rights that are particularly channelled towards achieving equality between the male and female gender. However, the societal treatment of the human rights of the female species is the focus of this work. In the various States that make up the Southern African Developing States, women have the same globally recognized rights enjoyed by their peers in other countries. These rights have been enunciated in various international instruments such as the Universal Declaration of Human Rights (UDHR), 1945 which is the foundation to most global treaties, Conventions and even Constitution of States. It provides that everyone, including women and girls have the right to life, liberty and the security of persons ${ }^{11}$ and that no one shall be held in slavery and slave trade shall be prohibited in all forms." 12 No one shall be subjected to torture or to cruel, inhuman or degrading treatment. By the provisions of the UDHR, nobody is above

${ }^{10}$ Van den Brink et al., "Equality and Human Rights: Nothing but Trouble," Liber AmicorumTitiaLoenen, SIM-Special, 38, 2011: 4-11.

${ }^{11}$ See Art. 3, Universal Declaration of Human Rights (UDHR) 1945; N. Bala, \& J.D. Redfearn, "Family Law and the Liberty Interest: Section 7 of the Canadian Charter of Rights," Ottawa L. Rev., 15, (1983): 274.

${ }^{12}$ Art. 4, Universal Declaration of Human Rights (UDHR) 1945; K. Bales, \& P. T. Robbins, "No One shall be held in Slavery or Servitude: A Critical Analysis of International Slavery Agreements and Concepts of Slavery," Human Rights Review, 2(2), (2001): 18-45. 
the law as they are, "all are equal before the law and entitled without any discrimination to equal protection of the law." 13

The UDHR recognizes the fundamental rights of women to choose whoever they wish to marry and to exercise equal rights with their men regarding their unions. Articles 16 and 17 of UDHR spell out the rights of man and woman who have attained full age to get married and form a family. Men and women have the same rights when they are married, and when they are separated. These provisions have abolished gender discrimination against any woman in marriage and even when she is separated or leaves alone after marriage. The same convention permits everyone to own things or share them. Nobody should take our things from us without a good reason. Everyone, as it is used here, connotes both male and female. The convention is all-encompassing such that man and woman have an equal right to freedom of thought, expression; they both have equal right to work. They also have equal freedom to the choice of employment; right to rest and leisure. The articles also empower them the right to a standard of living adequate for health; the right to education as well as right to freely participate in the cultural life of the community. ${ }^{14}$

In addition to the above provision, the International Covenant on Civil and Political Rights (ICCPR) also protects the sanctity of human life as evidenced in Article 6, thus: "Every human being which includes the girl-child has an inherent right to life; which right shall be protected

${ }^{13}$ See Art. 6, Universal Declaration of Human Rights (UDHR) 1945; M. A. Glendon, "The rule of law in the Universal Declaration of Human Rights," $N w$. UJ Int'l Human Rights, 2, (2004), 1.

${ }^{14}$ Art 16-30, Universal Declaration of Human Rights (UDHR) 1945; Wodon et al., Educating Girls and Ending Child marriage : A Priority for Africa (English): The Cost of Not Educating Girls Series, (Washington, D.C.: World Bank Group, 2018), 1-70, accessed ???? http://documents.worldbank.org/curated/en/268251542653259451/EducatingGirls-and-Ending-Child-marriage-A-Priority-for-Africa; Calimoutou et al., Compendium of International and National Legal Frameworks on Child Marriage, (Washington DC: International Bank for Reconstruction and Development/The World Bank, 2016): 21-30; Q. Wodon, "Global Welfare Cost of Child Marriage Due to Population Growth," Education Global Practice (Washington, DC: The World Bank, 2017); A. J. Veal, "Human rights, leisure and leisure studies," World Leisure Journal, 57(4), (2015): 249-272. 
by law as no one shall be arbitrarily deprived of his life. ${ }^{15}$ It also provides that, "no one shall be subjected to torture, or cruel inhuman or degrading treatment or punishment and no one shall be held in slavery or servitude. Everyone has the right to liberty and security of the person. However, no one shall be deprived of his liberty except on such grounds and in accordance with such procedures as are established by law."16

Furthermore, the Convention on the Elimination of all Forms of Discrimination against Women (CEDAW) gives credence to the above instruments that the traditional role of men and women in society and in the family are what is required to achieve full equality between men and women. It has also been observed that the establishment of the new economic order based on equity and justice has contributed significantly towards the promotion of equality between men and women." 17 Party states to the UDHR including, Nigeria had also agreed to modify the socio-cultural patterns of conduct of men and women with a view to eliminate all discriminatory customary practices which are based on the idea of the inferiority or superiority of either of the sexes or stereotyped roles for men and women. ${ }^{18}$ Unfortunately, the practicability is yet to be

15 Article 7, International Covenant on Civil and Political Rights (ICCPR) 1996.

${ }^{16}$ Articles 8-9, International Covenant on Civil and Political Rights (ICCPR) 1966; C. Macken, "Preventive Detention and the Right of Personal Liberty and Security under the International Covenant on Civil and Political Rights (1996)," Adel. L. Rev., 26, (2005): 1.

17 Convention on the Elimination of all forms of Discriminations against Women (CEDAW) 1979. See also K. N. Robertson, Defining Equity and Addressing the Social Determinants of Equity in International Development Evaluation, The Evaluation Center, (Michigan: Western Michigan University Kalamazoo, 2015): 1-30; M. Wadstein, "Implementation of the UN Convention on the Elimination of All Forms of Discrimination against Women," Neth. Q. Hum. Rts., 6, (1998): 5.

${ }^{18}$ Art. 5, International Covenant on Civil and Political Rights (ICCPR) 1996; Khosla Rajat et al., "Gender Equality and Human Rights Approaches to Female Genital Mutilation: A Review of International Human Rights Norms and Standards," Reproductive Health 14, no. 1 (2017): 59; Rikki Holtmaat and Paul Post, "Enhancing LGBTI Rights by Changing the Interpretation of the Convention on the Elimination of All Forms of Discrimination Against Women?" Nordic Journal of Human Rights 33, no. 4 (2015): 319-336; Article 5, CEDAW (2012). 
felt in Nigeria due to strong attachment to custom. For instance, despite the fact that CEDAW frowns against child labour, children are still allowed to roam the streets, hawking, in order to help their family members to make ends meet. Some children, especially girls, are used for trafficking as soon as they are given to uncles or aunties who normally promise to give them the right education in urban areas. Some parents still give out their daughters as housemaids to strangers who sometimes, in turn, use these girls for money rituals. These are just a few instances where the law needs to be enforced to checkmate the acts of these violators and to bring them to book in order to put an end to discriminatory practices against the female gender.

\section{Discriminatory Customary Practices Against Gender Rights and State's Intervention Strategies in the Southern African Development Community}

The Southern African Development Community (SADC) is a regional economic community consisting of fifteen (15) member states established in 1992. The community is committed to regional integration and poverty eradication within Southern Africa. The member states include; Angola, Botswana, Democratic Republic of Congo, Lesotho, Madagascar, Malawi, Mauritius, Mozambique, Namibia, Seychelles, South Africa, Swaziland, United Republic of Tanzania, Zambia, Zimbabwe. The body is aimed at creating common political values, systems and institutions; build social and cultural ties; alleviate poverty; uphold human rights and the rule of law. ${ }^{19}$ The following are the common cultural practices found in these states before the establishment of this body, which had greatly influenced the application of the rights of women and the girl-child in the region. For instance, in South Africa, Swaziland and Lesotho there is an orthodox belief that sexual

19 J. W. M.Mapuwa, "The SADC Regional Bloc: What Challenges and Prospects for Regional Integration?" Law, Democracy \& Development 18, no. 1 (2014): 22-36; Tanaka Aggrey Chista, "Challenges of Regionalism in Africa and Regional Integration in Africa, A Case Study of the Southern African Development Community (SADC), 1992-2014," (2016):28-40; Mohabe Nyirabu, "Appraising Regional Integration in Southern Africa," African Security Studies 13, no. 1 (2004): 21-32; Harry Stephan and Angus Fane Hervey, "New Regionalism in Southern Africa: Functional Developmentalism and the Southern African Power Pool," Politeia 27, no. 3 (2008): 54-76. 
intercourse with a young virgin girl can cure HIV and AIDS. This has led to an increase in sexual violence against girls resulting in huge psychological scars on the victims. The traditional practices such as polygamy, payment of bride price (lobola) and child marriages are all synonymous with gender violence as they reduce women to sub-human assets belonging to men. Payment of bride price and child marriages take place in most SADC member states as part of traditional culture, ignoring changes in social contexts. ${ }^{20}$

Some of the other cultural practices, which are common to the member States include female genital mutilations of various degrees, child abduction and child marriages. There is also the sale of the girlchild through the payment of bride prices and the general disinheritance of the girl-child. Although the female genital mutilations are generally practised in the SADC States but it is more prevalent in Tanzania and Malawi where the ritual is performed on young girls. ${ }^{21}$ Female genital mutilations (FGM) are compulsory among the ethnic groups, while it is not easy for ladies who fail to undergo this practice to get husbands.

${ }^{20}$ Iyanuolu, Atoyebi, "The Challenge of Culture for the Rights of Women in Africa: A Critical Analysis of the Protocol to the African Charter on Human and Peoples' Rights on the Rights of Women in Africa," (PhD diss., University of Cape Town, 2014); Rembe et al., "Child and Forced Marriage as Violation of Women's Rights, and Responses by Member States in Southern African Development Community," Agenda25, no. 1 (2011): 65-74; Wadesango et al., "Violation of Women's Rights by Harmful Traditional Practices," The Anthropologist 13, no. 2 (2011): 121-129; John Cantius Mubangiz, "A South African Perspective on the Clash between Culture and Human Rights, with Particular Reference to Gender-Related Cultural Practices and Traditions," Journal and Campus Publications JIWS 13, no.3 (2012): 1-2 ; Makho Nkosi, "Bride Abduction in KwaZuiu-Natal Schools and its Effects on Education," Agenda 23, no. 80 (2009): 109-114.

21 Droy et al., "Alternative Rites of Passage in FGM/C Abandonment Campaigns in Africa: A Research Opportunity," LIAS Working Paper Series 1 (2018). See also Norah Hashim Msuya, "Tradition and Culture in Africa: Practices that Facilitate Trafficking of Women and Children," Dignity: A Journal on Sexual Exploitation and Violence 2, no. 1 (2017): 3; Lotte Hughes, "Alternative Rites of Passage: Faith, Rights, and Performance in FGM/C Abandonment Campaigns in Kenya," African Studies 77, no. 2 (2018): 274292. 
However, in some regions, mass circumcisions are carried out openly where thousands of girls' genitals are mutilated at the same time. For instance, in Malawi, FGM entails cutting off the tips of girls' clitoris by a traditional nurse/counsellor using fingernails. ${ }^{22}$ This is followed by inserting an egg or a wooden penis the size of a soft drink bottle in the vagina to widen it to accommodate any size of the penis. ${ }^{23}$ This is a clear case of invasion of the girl's privacy and can lead to serious health challenges.

Marriage by abduction is also a common practice found in some of the SADC countries and especially in Zimbabwe and South Africa. This is a situation where, a girl is abducted by a gang, on the authority of her

${ }^{22}$ Natasha Recchia and Julie McGarry, "Don't Judge Me": Narratives of Living with FGM," International Journal of Human Rights in Healthcare 10, no. 1 (2017): 4-13; Cappon Sien et al., "Female Genital Mutilation: Knowledge, Attitude and Practices of Flemish Midwives," Midwifery 31, no. 3 (2015): e29e35; Iyanuolu, Atoyebi, 34-49. See also Rigmor C. Berg and Eva M. Denison, "A realist synthesis of controlled studies to determine the Effectiveness of Interventions to Prevent Genital Cutting of Girls," Paediatrics and International Child Health 33, no. 4 (2013): 322-333; Khamasi et al., "Transcending Female Circumcision: A Call for Collective Unmasking," Interrogating HarmfulCultural Practices. Gender, Culture and Coercion (2015): 99-110; Galukande et al., "Eradicating Female Genital Mutilation and Cutting in Tanzania: An Observational Study," BMC public health 15, no. 1 (2015): 1147; K Chinnian-Kester, "Female Genital Mutilation as A Form of Violence against Women and Girls: An Analysis of the Effectiveness of International Human Rights Law," (Unpublished Masters' Thesis, Cape Town: University of Western Cape, 2005), p. 46.

${ }^{23}$ Marc H. Bornstein et al., "Gender in low-and middle-income countries: General methods," Monographs of the Society for Research in Child Development 81, no. 1 (2016): 24; Iyanuolu, Atoyebi; Kate Rice, "Ukuthwala in rural South Africa: Abduction Marriage as a Site of Negotiation about Gender, Rights and Generational Authority among the Xhosa," Journal of Southern African Studies 40, no. 2 (2014): 381-399; Erika R. George, "Virginity Testing and South Africa's HIV/AIDS Crisis: Beyond Rights Universalism and Cultural Relativism Toward Health Capabilities." Calif. L. Rev. 96 (2008): 1447; Malawian Government 2006, "National Progress Report on World fit for Children (WFFC)," (2006): 1-40; Lea Mwambene and Obdiah Mwaodza, "Children's Rights Standards and Child Marriage in Malawi," African Studies Quarterly 17, no. 3 (November, 2017): 1-24. 
proposed husband. She is kept hidden and raped to make her succumb to the marriage after which family members from both sides meet and discuss marriage rites between the abducted girl and the would-be husband. By this method, she is effectively forced into marriage without her consent. ${ }^{24}$ Another form of abduction commonly practised in the region is called the ukuthwala custom or bride abduction especially among some rural Xhosa communities in the Transkei in South Africa. The procedure in the instant case is that the intending groom with some of his friends waylaying the proposed bride and forcibly taking her to the young man's home. He sleeps with her like a wife and then sends a message to the girl's home informing her family of their daughter's safety with them. The family will, in turn, proceed to call for the brideprice called "lobolo" (Cattle is usually accepted as pride price). Once this is done, the status of the girl is immediately elevated to that of a young wife. Girls between twelve (12) and fifteen (15) years old are usually targeted for this kind of abduction. ${ }^{25}$ Unfortunately, this practice

${ }^{24}$ Lunga Siyo and John Cantius Mubangizi, "The Independence of South African Judges: A Constitutional and Legislative Perspective," Potchefstroom Electronic Law Journal/Potchefstroomse Elektroniese Regsblad 18, no. 4 (2015): 817-846; Wadesango et al., "Benign Accommodation? Ukuthwala, 'Forced Marriage' and the South African Children's Act," African Human Rights Law Journal 11, no. 1 (2011): 1-22.

25 Chelete Monyane, "Is Ukuthwala Another Form of 'Forced Marriage'?" South African Review of Sociology 44, no. 3 (2013): 64-82; Kate Rice, 381-399; Lea Mwambene and Julia Sloth-Nielsen. See also W. J. Smit and Catrien Notermans. "Surviving change by changing violently: Ukuthwala in South Africa's Eastern Cape province," Anthropology Southern Africa 38, no. 1-2 (2015): 29-46; Benard O.Itebiye, "Forced And Early Marriages: Moral Failures vs Religious Nuances," European Scientific Journal, ESJ 12, no. 17 (2016): 305; O.O. Adeyemo, "Early and Forced Marriages in an African System: An Appraisal of the Rights of the Child in Nigeria," Nigerian Journal of Family Practice 4, no. 2 (2013): 27-34; Laws, "Women Living Under Muslim, Child, Early and Forced Marriage: A Multi-Country Study," A Submission to the UN Office of the High Commissioner on Human Rights $(O C H C R)(2013)$; Sauti etu, "A Closer Look at Forced and Early Marriages in African Immigrant Communities in New York City," SautiYetu Occasional Report 3 (2012); Anitha, Sundari, and Aisha K. Gill, "Reconceptualising Consent and Coercion within an Intersectional Understanding of Forced Marriage," Forced Marriage, Introducing A Social (2011). 
has greatly hampered the enforcement of girl-child rights. Commenting on the adverse effects of this kind of abduction marriages, TshabalalaMsimang has this to say,

"Child marriage is regarded as a form of gender-based violence against the girl-child. Given this, we need to acknowledge that this practice will ultimately compromise the development of the girl-child and can result in early pregnancies, increasing the chances of maternal mortality. ${ }^{26}$

Furthermore, young girls suffer from social isolation, with little or no education and poor vocational training. They are made responsible for household chores to take care of family members at a younger age, which increases their vulnerabilities to domestic violence. This simply reinforces the gendered nature of poverty." ${ }^{27}$ This goes to say that child marriages of various forms, which are recognized in the SADC region are nothing but a violation of human rights whether it happens to a girl or a boy. This is a pure representation of one of the most prevalent forms of sexual abuse and exploitation of girls. ${ }^{28}$

26 M.Tshabalala-Msimang, "Girl Child Abductions, Forced and Early Marriages," (An Address by MantoTshabalala-Msimang, Minister in The Presidency during the Lusikisiki Imbizo, March, 24, 2009), accessed July, 30, 2015, <http://www.thepresidency.gov.za>; Corno et al., "Age of Marriage, Weather Shocks, and the Direction of Marriage Payments, No. w23604," National Bureau of Economic Research, (2017); Norah Hashim Msuya, "Tradition and Culture in Africa."

${ }^{27}$ Mark V. Sauer, "Reproduction at an advanced maternal age and maternal health," Fertility and sterility 103, no. 5 (2015): 1136-1143; Godha et al., "Association between Child Marriage and Reproductive Health Outcomes and Service Utilization: A Multi-Country Study from South Asia," Journal of Adolescent Health 52, no. 5 (2013): 552-558; Santhya et al., "Associations between Early Marriage and Young Women's Marital and Reproductive Health Outcomes: Evidence from India," International Perspectives on Sexual and Reproductive Health (2010): 132-139; Raj et al., "Association between Adolescent Marriage and Marital Violence among Young Adult Women in India," International Journal of Gynecology \& Obstetrics 110, no. 1 (2010): 35-39.

${ }^{28}$ Adeniyi, Olayinka Oluwakemi, "Legal Protection of the Girl Child against Child Marriage (AureYarinya) in Nigeria," (PhD diss., University of Pretoria, 2016); Martin, Patricia, and Buyi Mbambo, "An Exploratory Study on the 
According to Wadesango et al, child marriages are practised in Zimbabwe. ${ }^{29}$ It takes the form of parents luring a male tenant on an estate who is hard working and has shown high prospects in his financial pursuit, into marrying their teenage daughter by using her as payment for work done as they would claim lack of capacity to pay for his services. Whilst, the practice in some parts of Tanzania especially among pastoral groups is that parents send girls as young as nine (9) years old to stay with rich men with the understanding that the rich man will come later to pay the bride price either in money or in cattle. ${ }^{30}$ In some parts of Zimbabwe, Malawi, Zambia, Lesotho and South Africa the younger sister or niece of his wife is given to the husband as a bonus (second) wife; whilst in Malawi and Zimbabwe, infant girls may be married off

Interplay between African Customary Law and Practices and Children's Protection Rights in South Africa," (2011): 21-25; Buluma Bwire, "Integration of African Customary Legal Concepts into Modern Law: Restorative Justice: A Kenyan Example," Societies 9, no. 1 (2019): 17; Newman Wadesango, Symphorosa Rembe, and Owence Chabaya, "Violation of Women's Rights by Harmful Traditional Practices," The Anthropologist 13, no. 2 (2011): 121-129; Redson Edward Kapindu, "Separation of Powers and the Accountability Role of NHRIs: the Malawi Human Rights Commission through the Courts," in The Evolution of the Separation of Powers, ed. David Bilchitz and David Landau, (Cheltenham, UK; Northampton, MA, USA: Edward Elgar Publishing, 2018), 18-22; Tinashe Kondo, "Socio-Economic Rights in Zimbabwe: Trends and Emerging Jurisprudence," African Human Rights Law Journal 17, no. 1 (2017): 163-193; L. Chiduza, "The Zimbabwe Human Rights Commission: Prospects and Challenges for the Protection of Human Rights," Law, Democracy \& Development 19, no. 1 (2015): 148-174.

29 Mediel Hove, "Nonviolent campaigns in Zimbabwe, 1999 to 2013: Strategies, Methods and Effectiveness," (PhD dissertation, Durban University of Technology, South Africa, 2016): Hove et al., "Violent State Operations at Chiadzwa (Zimbabwe) Diamond Fields 2006-2009," Journal of Aggression, Conflict and Peace Research 6, no. 1 (2014): 56-75; Tappis Hannah et al., "Effectiveness of Interventions, Programs and Strategies for Gender-Based Violence Prevention in Refugee Populations: an Integrative Review," PLoS currents 8 (2016).

${ }^{30}$ Valerie M. Hudson, and Hilary Matfess, "In Plain Sight: the Neglected Linkage Between Bride- price and Violent Conflict," International Security 42, no. 1 (2017): 7-40; Valerie M. Hudson, and Hilary Matfess, "The Neglected Role of Bride price in Catalyzing Instability and Violent Conflict," Military Review (2018). 
for monetary gain or repayment of family debts or as a compensation for pledging. ${ }^{31}$

Another identifiable traditional practice, which violates women and the girl-child rights' to the dignity of the human person and equality is the virginity test approved by traditional rulers in most of the SADC States. According to Kaarsholm, "virginity test is another cultural practice which violates the rights of women, especially girls. This practice was common in African societies in the nineteenth century and is now enjoying contemporary revival and popularity after a long period of dormancy." ${ }^{32}$ Virginity tests, according to Chirau, were used to bargain for a high bride price by parents. This practice, however, exposes the girl-child to certain indignities of inspection of her private parts, in addition to possible ridicule and stigmatization in the event that she failed the virginity test. As Le Roux states:

"The female participants' right to equality is infringed by this practice being predominantly applicable to women only. This unfairly places the responsibility of being sexually active on women. Failing virginity tests leads to stigmatization and mocking by other participants as well as the community." 33

This is undignified as the girls are humiliated in the process. The pressure by the community to take part in this ritual also infringes the

${ }^{31}$ Victoria Balogun and Ebenezer Durojaye, "The African Commission on Human and Peoples' Rights and the Promotion and Protection of Sexual and Reproductive Rights," African Human Rights Law Journal, 11 (2), 2011: 368395; Khosla Rajat et al., "International Human Rights and the Mistreatment of Women during Childbirth," Health and Human Rights 18, no. 2 (2016): 131; Peter K.. Koech, and Wilfred K.. Njeru, "A Critical Analysis of the Implementation of Children's Rights in Kenya," Educational Research International 3, no.6, December, (2014):1-6.

${ }^{32}$ Mashele Rapatsa, "South Africa's Post-1994 Transformative Constitution and Its Human Rights Narrative: A View on Perfecting Traditional Male Circumcision," Socio-economica-Naučni časopis za teoriju i praksu društvenoekonomskog razvoja 4, no. 8 (2015): 395-406; John C. Mubangizi, "A Human Rights-based Approach to Development in Africa: Opportunities and Challenges." Journal of Social Sciences 39, no. 1 (2014): 67-76.

${ }^{33}$ L. Le Roux, "Harmful Traditional Practices (Male Circumcision and Virginity Testing of Girls) and the Legal Rights of Children," (Unpublished Masters' Thesis, University of Western Cape, 2006): 64. 
participant's right to bodily integrity. This right to bodily integrity is provided under the South African domestic legislation. ${ }^{34}$ In South Africa however, virginity testing is generally prohibited by law except in certain conditions $;{ }^{35}$ while in Zimbabwe, there is no law that prohibits virginity testing although sexual abuse and exploitation of children are covered under the Criminal Law (Codification) Act $257 .{ }^{36}$ However, with the coming together of these states, the governments of each of the SADC States have taken legislative and other measures to outlaw these traditional and cultural practices which violate the rights of women and the girl-child in the region, though the effectiveness of these measures is still debatable. For instance, in Tanzania, economic empowerment was introduced to improve women's social status. According to Mariam Mwaffisi ${ }^{37}$ Tanzania is committed to attaining gender equality and

${ }^{34}$ S. 12(2) Chapter Two, Constitution of South Africa 1997 which contains the Bill of Rights provides for the right to bodily and psychological integrity which includes the right to make decisions concerning reproduction, to security in and control over their body; and not to be subjected to medical or scientific experiments without their informed consent.

35 S. 12(4) Children's Act of South Africa 2005 which prohibits virginity testing of children under the age of 16, although S.12 (5) allows virginity testing provided the following conditions are met, namely: (a) if the child has given consent to the testing in the prescribed manner;(b) after proper counselling of the Child; and (a) in the manner prescribed. Section 12 (6) emphasize that disclosure of the results of virginity testing may not be made known without the consent of the affected child while section 12 (7) outlaws marking of the body of the child who has undergone such testing. See also Ebenezer Durojaye, "The Human Rights Implications of Virginity Testing in South Africa," International Journal of Discrimination and the Law 16, no. 4 (2016): 228-246; Jabulile Favourite Mbulu, "Exploring the Experience of Virginity Testing by Female Adolescents in the uThungulu District of Kwazulu-Natal," (PhD diss., University of South Africa, 2016), 17-22; Anette Wickström, "Virginity Testing as A Local Public Health Initiative: A 'Preventive Ritual' More Than a 'Diagnostic Measure," Journal of the Royal Anthropological Institute 16, no. 3 (2010): 532-550.

${ }^{36}$ R. Hanzi, 'Sexual Abuse and Exploitation of the Girl Child through Cultural Practices in Zimbabwe: A Human Rights Perspective," (Unpublished Masters' Thesis, Centre University of Pretoria, 2006): 41.

${ }^{37}$ Mariam Mwafisi was a permanent Secretary in the Ministry of Community Development, Gender and Children in Tanzania. She was involved in the child rights. She made this statement in her capacity as a state official. She also took 
women empowerment; and its achievements in this regard included gender parity in education enrolment and the formation of science camps for the girls. ${ }^{38}$

The government has also surpassed the thirty percent (30\%) threshold for women in public service and parliament and is now reaching fifty percent (50\%). To curtail violence against women and the girl-child, the government has established a National Action Plan on the prevention and eradication of violence against women and children through a campaign tagged "Say NO to violence against women," in Tanzania. The government has also taken steps to improve the status of women by actively promoting savings and credit societies in both rural and urban areas, introducing a Social Action Fund and a Woman's Bank to provide women with required training and credit for businesses. The Tanzanian government has also enacted relevant laws to ensure access and ownership of land by women.

In this relation, most of the States of the SADC have also ratified the CEDAW and the Convention on the Rights of the Child (CRC). Article 2 of the CRC has urged states to prohibit gender discrimination and recognize the principle of equality. ${ }^{39}$ The same convention has also

part in the third Global Forum, The 10/90 Report on Health Research 20012002 , focuses on the crucial role of health and health research in the fight against poverty; progress in the definition of priorities for health research; the development of partnerships and networks in key research areas; and the application of a new tool for developing the priority research agenda. The Report covers progress in helping correct the 10/90 gap in health research over the past two years and outlines plans for the coming years. The report is available at http://www.globalforumhealth.org/pages/index.asp took part in the Health research.

${ }^{38}$ Lars Ivar Oppedal Berge et al., Reducing Early Pregnancy in Low-Income Countries: A Literature Review and New Evidence, (no. 2017/133, WIDER Working Paper, 2017): 1-29; B.P. Mlyakado, "Gender and Education Opportunities in Tanzania: Do We Bridge the Gap of Quality," Academic Research International, 3(3),(2012): 246.

${ }^{39}$ Khosla Rajat et al.,"Gender Equality and Human Rights Approaches,"; See also Penwell J. Barnett, Eleanor Maticka-Tyndale, and Trócaire Kenya, "Stigma As Social Control: Gender-Based Violence Stigma, Life Chances, and Moral Order in Kenya," Social Problems 63, no. 3 (2016): 447-462; S. Doris Buss and Emily S. Burrill, Marriage by Force?: Contestation over Consent 
identified some grey areas and communicated these to the states for reforms to be made both in civil and penal legislation including the minimum age for marriage. Its argument is that where a girl gets matured earlier than the age stipulated for marriage; this must not be interpreted to mean maturity (adult) nor must she be deprived of the protection as provided under the CRC. Hence, every state has been advised to fix the minimum age for marriage in accordance with the provisions of the Convention. The marriageable age in most of these countries is eighteen years old while in Madagascar and Tanzania is sixteen years old. ${ }^{40}$

There are however differences in minimum ages of marriage for boys and girls in Madagascar, Malawi, Mozambique, South Africa, Tanzania and Zimbabwe. There are also age differences under the marriage laws and under customary law. ${ }^{41}$ According to Jonas, these differences in law exist in Tanzania by virtue of section 13 of the Law of

and Coercion in Africa, (Ohio University Press, 2016), 1-5; S. Besson, "The Principle of Non-Discrimination in the Convention on the Rights of the Child," International Journal of Children's Rights, 13(4), (2005): 433.

${ }^{40}$ Alissa Koski, "Child Marriage in Sub-saharan Africa: Trends, Effects on Health, and Efforts to Limit the Practice," (PhD diss., McGill University Libraries, 2016): 57-74; Belinda Maswikwa et al., "Minimum Marriage Age Laws and the Prevalence of Child Marriage and Adolescent Birth: Evidence from Sub-Saharan Africa," International Perspectives on Sexual and Reproductive Health 41, no. 2 (2015): 58-68; Endale Kebede, Anne Goujon, and Wolfgang Lutz, "Stalls in Africa's Fertility Decline Partly Result from Disruptions in Female Education," Proceedings of the National Academy of Sciences116, no. 8 (2019): 2891-2896; John Bongaarts and John Casterline, "Fertility Transition: is Sub-Saharan Africa Different?," Population and Development Review 38, (2013): 153-168; Nawal M. Nour, "Child Marriage: A Silent Health and Human Rights Issue," Reviews in Obstetrics and Gynecology 2, no. 1 (2009): 51.

${ }^{41}$ Lunga Siyo and John Cantius Mubangizi, "The Independence of South African Judges: A Constitutional and Legislative Perspective," Potchefstroom Electronic Law Journal/Potchefstroomse Elektroniese Regsblad 18, no. 4 (2015): 817-846; Aidan Mulkeen and Dandan Chen, eds, "Teachers for Rural Schools: Experiences in Lesotho, Malawi, Mozambique, Tanzania, and Uganda, (The World Bank, 2008); Mashamba Julius Clemet, "A Study of Tanzania's Non-Compliance with its Obligation to Domesticate International Juvenile Justice Standards in Comparison with South Africa," (PhD diss., The Open University of Tanzania, 2013): 78-96. 
Marriage Act which has fixed the age of marriage for eighteen (18) years and above. Whilst girls can be married at the age of fifteen (15) with the consent of the father. ${ }^{42}$ This duty (consent) shifts to the mother when a father dies, although the marriage of girls below fifteen years but not below fourteen years is permitted by court order. This position to Jonas is discriminatory towards girl-child and a violation of the rights of the child. ${ }^{43}$ It is apparent from the foregoing that eventhough appropriate laws have been made, they are still not consistent and effectual nor sufficiently protecting children especially the girl-child from early marriages.

In another region within these states, it is the parents and not the child's consent that is required to give validity to the marriage. It is thus clear that children do not receive the required protection of the law because some of their parents still push for early marriages in order to

\footnotetext{
${ }^{42}$ The Tanzania Law of Marriage Act, of 1971 [CAP 29 RE 2002]; B. Jonas, "Towards Effective Implementation of Children's Rights in Tanzania: Lessons and Opportunities from Ghana and South Africa," (Unpublished Master Thesis, University of Pretoria, South Africa, 2006): 54; Mona Sandbæk, "European Policies to Promote Children's Rights and Combat Child Poverty," International journal of Environmental Research and Public Health 14, no. 8 (2017): 837; Michael G. Wessells, "Bottom-Up Approaches to Strengthening Child Protection Systems: Placing Children, Families, and Communities at the Center," Child Abuse \&Neglect 43 (2015): 8-21; Lois Pierce and Vivienne Bozalek, "Child Abuse in South Africa: An Examination of How Child Abuse and Neglect are Defined," Child Abuse \& Neglect 28, no. 8 (2004): 817-832; Philista Onyango and Margaret A. Lynch, "Implementing the Right to Child Protection: A Challenge for Developing Countries," The Lancet 367, no. 9511 (2006): 693-694.

${ }^{43}$ Laura Stark, "Early Marriage and Cultural Constructions of Adulthood in Two Slums in Dar es Salaam," Culture, Health \& Sexuality 20, no. 8 (2018): 888-901; Jukka Jouhki and Laura Stark, "Causes and Motives of Early Marriage in the Gambia and Tanzania: is New Legislation Enough?" Poverty and Development Working Papers 2017, 1 (2017): 12-15; Amana Talala Mbise, "The Diffusion of the United Nations Convention on the Rights of the Child (UNCRC) more than the African Charter on the Rights and Welfare of the Child (ACRWC) in Africa: The Influence of Coercion and Emulation," International Social Work 60, no. 5 (2017): 1233-124; S. 2 Convention on the Rights of the Child (1989) \& S.21 of African Charter on the Rights and Welfare of the Child 1989.
} 
acquire wealth. ${ }^{44}$ This situation calls for more work by these States in the area of strategizing for the effective enforcement and protection of the rights of women and children in this region. Hence this paper tends to look at some of these states where customary practices still prevalent despite the adoption of CEDAW and other conventions which kick against gender discrimination.

\section{Discriminatory Customary Practices on Gender Rights and State's Intervention Strategies in Kenya}

Various forms of discriminations of the girl-child's rights emanating from customary practices also exist among different communities and tribes in Kenya. For instance, among the Masai people, the girl-child is forced to marry early to provide wealth to the natal family. This practice discourages investment of parents into the education and training of the girl-child, who, according to custom would soon belong to another family who will then enjoy the benefits of her training. They are also subjected to the indignities of female genital mutilations (FGM) and discriminatory inheritance rights. Another tribe known as Luo in Kenya give their girls as compensation in a murder case. According to Thandabantu, the customary law of the Luo people permits restitution in homicide cases where the clan of a murderer is required to "provide a girl to bear progeny in the name of the deceased." This means that the girl-child's will is "sold" or surrendered" to the family of the murdered victim for the purpose of procreation as a replacement of the dead. Also

\footnotetext{
${ }^{44}$ Jennifer Parsons et al., "Economic Impacts of Child Marriage: A Review of the Literature," The Review of Faith \& International Affairs 13, no. 3 (2015): 12-22; Joar Svanemyr et al., "Research Priorities on Ending Child Marriage and Supporting Married Girls," Reproductive health 12, no. 1 (2015): 80; Emma C. Jackson et al., "Beyond the Statistic: Exploring the Process of Early Marriage Decision-Making using Qualitative Findings from Ethiopia and India," BMC Women's Health, accessed on March 23, 2018, <https://doi.org/10.1186/s12905-018-631z>; Cynthia B. Lloyd and Barbara S. Mensch, "Marriage and Childbirth as Factors in Dropping out from School: An Analysis of DHS Data from Sub-Saharan Africa," Population Studies 62, no. 1 (2008): 1-13; R. L. Abel, "Customary Laws of Wrongs in Kenya an Essay in Research Method," The American Journal of Comparative Law, 17(4), (1969): 573-626.
} 
among the Gusii, girls are required to marry early before attaining 15years of age.

Premarital intercourse is also rampant; where a girl had intercourse before marriage her bridewealth shall be deducted. ${ }^{45}$ Furthermore, a Gusii husband has control of the wife after the payment of the bride price. He is also by tradition allowed to shave the hair of his wife. He must keep the shaved hair to enable him to retain the wife. The essence of this shaving is to put the public on notice that she is under a man. However, if she leaves the husband in this situation, she is regarded as a disobedient wife and a suspected adulteress. ${ }^{46}$

This process, of course, stigmatizes the girl-child and also a violation of her right to dignity of the human person. The Nandi culture, on the other hand, permitted elderly women who were childless to marry other women to bear children for them in a woman to woman marriage system. ${ }^{47}$ Daughters are generally regarded as non-permanent members

${ }^{45}$ Thandabantu Nhlapo, "Homicide in Traditional African Societies: Customary Law and the Question of Accountability," African Human Rights Law Journal 17, no. 1 (2017): 1-34; Aimé Muyoboke Karimunda, "The Death Penalty in Africa: The Path Towards Abolition," (London: Routledge, 2016), 25; Natasha L. Frosina and Grace M. Mwaura, "An Assessment of Gender Mainstreaming in STI and the Knowledge Society in Kenya," African Centre for Technology Studies (2016); Ganira et al., "Early and Forced Child Marriage on Girls' Education, in Migori County, Kenya: Constraints, Prospects and Policy," World Journal of Education 5, no. 4 (2015): 72-80; Ruth Michael Kanyangu, "Factors Contribute to Early Marriage Among Teenagers in Rural Areas in Kasulu District Council," (PhD diss., The Open University of Tanzania, 2014); I. Nnadi, "Son Preference- A Violation of Women's Human Rights: A Case Study of Igbo Custom in Nigeria," J. Pol. \& Law, 6, (2013), 134.

${ }^{46}$ Beatrice Kemunto C. Obwoge, "A lexico-Semantic Analysis of EkeGusii Circumcision Social Varieties," (PhD diss., University of South Africa, 2014): 9-12.

${ }^{47}$ Monicah Wanjiru Kareithi, "A Historical-Legal Analysis of Woman-toWoman Marriage in Kenya," (PhD diss., University of Pretoria, 2018); Hephzibah Egede, "The Social Stigmatisation of Involuntary Childless Women in Sub-Saharan Africa: the Gender Empowerment and Justice Case for Cheaper Access to Assisted Reproductive Technologies?" (PhD diss., Cardiff University, 2015); Elizabeth Cooper, "Women and Inheritance in 5 SubSaharan African Countries: Opportunities and Challenges for Policy and 
of their natal families and so are excluded from the inheritance of land and property. In fact according to Harrington and Chopra, "daughters have great difficulty accessing land through inheritance since marriage would transfer the lands outside the natal holdings and into their husband's hands. " cultural violations of the rights of the girl-child through legislation and by the ratification of international human rights instruments such as the International Covenant on Economic, Social and Cultural Rights (ICESCR) in 1976, the UN Convention on the Rights of the Child (CRC) in 1990, International Convention on Civil and Political Rights (ICCPR), UN Convention against Torture (CAT), the African Charter on Human and Peoples Rights, the African Union Solemn Declaration on Gender and Equality (2004).

The Kenyan Constitution also provides that any treaty or Convention ratified by the government shall form part of the laws of Kenya. ${ }^{49}$ The Constitution recognizes customary law but invalidates it to the extent that it conflicts with the provisions of the Constitution. ${ }^{50}$ On

Practice Change," Chronic Poverty Research Centre/Overseas Development Institute Roundtable on Inheritance and the Intergenerational Transmission of Poverty, London 11 (2010): 1-17; Ngozi O. Odiaka, "The Concept of Gender Justice and Women's Rights in Nigeria: Addressing the Missing Link," Journal of Sustainable Development Law and Policy (The) 2, no. 1 (2013): 190-205. ${ }^{48}$ Elishiba N. Kimani and Lucy W. Maina, "Older women's rights to property and inheritance in Kenya: Culture, policy, and disenfranchisement," in Women and Aging International, (Routledge, 2013): pp. 11-26, 1-16; Miller et al., "Family Histories and Rural Inheritance in Kenya," (CPRC Working Paper 220, Manchester, UK: Chronic Poverty Research Centre (CPRC), 2011): 1-45. ${ }^{49}$ See Art. 2 (6) of Constitution of Kenya 2010; Robert Doy Nanima, "An Evaluation of Kenya's Parallel Legal Regime on Refugees, and the Courts' Guarantee of their Rights," Law, Democracy \& Development 21, no. 1, (2017): 42-67; Andrew McGregor, "After Garissa: Kenya Revises Its Security Strategy to Counter al-Shabaab's Shifting Tactics," Terrorism Monitor 13, no. 8 (2015); T. Kabau \& Njoroge, C, "The Application of International Law in Kenya under the 2010 Constitution: Critical Issues in the Harmonisation of the Legal System," Comparative and International Law Journal of Southern Africa, 44(3), (2011): 293-310.

${ }^{50}$ Fatimah Oluwakemi Bello et al., "The Role of Women's Empowerment and Male Engagement in Pregnancy Healthcare Seeking Behaviors in Western Kenya," Women \& health (2019): 1-15; Shirley Aggrey Mlimuka, "A 
issues bordering on the enforcement of the rights of women and children in Kenya, the old 1969 Kenyan Constitution harboured some discriminatory laws, which were not supportive of women and girl-child rights. For example, the Constitution's guarantee of non-discrimination does not apply with respect to personal laws, in particular in the areas of marriage, divorce, adoption, burial and succession. It also did not provide equal citizenship rights for women and it recognized the application of customary laws in Kenya in cases related to marriage, divorce, death and inheritance issues. In addition, the Matrimonial Property Bill and the Equal Opportunities Bill is proposed to further promote women's rights, eradicate female genital mutilations permitted by customary law while the enactment of the Domestic Violence (Family Protection) Bill has been pending since 2002.

Legislative changes with regard to gender issues have been impeded by the fact that there have been a lot of delays in parliament regarding some key gender-related bills which, if passed, would go a long way within cultural contexts in addressing some of the discriminatory issues affecting women with regard to matrimonial issues, property rights and inheritance although the amendment of the1969 Constitution, which gave birth to a new Constitution which attempted to address some of these issues.

However, there is no statutory definition as to what could amount to discrimination against women in the Kenyan Constitution as well as in any other local legislation. A general/working definition of torture is also lacking in all Kenyan statutes. This is as good as failing to provide a basis for tackling issues of discrimination in all spheres. For instance, the constitution and law prohibits torture while the legal code does not define torture and provides no sentencing guidelines for violating the constitutional and legal prohibitions. ${ }^{51}$ However, the current Kenyan

Perspective of the Role of Tanzanian National Courts in Commercial Arbitration," (PhD diss., University of Cape Town, 2014): 18-31.

${ }^{51}$ Eugene Lubale Lubulellah, "College Of Humanities and Social Sciences School of Law," (PhD diss., University of Nairobi, 2017), 153-154; Malose Langa, "Analysis of Existing Data on Torture in South Africa with Specific Focus on Annual Reports Published by IPID and JICS," (Cape Town: IPID and JICS, 2014): 33-40; Akmal Niyazmatov, "Evidence Obtained by Cruel, Inhuman or Degrading Treatment: Why the Convention against Torture's 
Constitution of 2010 shows a strong commitment to principles of equality and non-discrimination. It specifically provided that every person is equal before the law.

Equality here includes full and equal enjoyment of all rights and fundamental freedoms. Women and men have rights to equal treatment including the right to equal opportunities in political, economic, cultural and social spheres. ${ }^{52}$ It also provides for the elimination of gender discrimination in law, customs and practices. It expressly states that land rights under customary law are to be respected and fully compensated unless they are repugnant to written law. ${ }^{53}$ The Constitution made

Exclusionary Rule Should be Inclusive," (Conferences, Lectures, and Workshops, held at the Cornell Law School Inter-University Graduate Student Conference Papers on June 6, 2011): 32-36; See also Nicole O'Neal, "Corporal punishment in public schools: A call for Legal Reform," African Human Rights Law Journal 8, no. 1 (2008): 60-78; J. Paust, "The Absolute Prohibition of Torture and Necessary and Appropriate Sanctions," Val. UL Rev. 43 (2008): 1535.

${ }^{52}$ Steven G. "Is the prohibition against torture, cruel, inhuman and degrading treatment really 'absolute." International human Rights Law 15 (2015): 101137; E. Kimani, "Perception of Youth on Women's Rights to Ownership and Control of Matrimonial Property," American Journal of Arts and Humanities 1 (2016): A12-A24: 1-13; Patricia Kameri-Mbote, "Women, Land Rights and the Environment: the Kenyan Experience," Development 49, no. 3 (2006): 43-48; Art 27 Constitution of Kenya 2010 which provides the right to equality and freedom from discrimination under the Bill of Rights; Elizabeth Cooper, "Women and Inheritance in 5 Sub-Saharan African Countries: Opportunities and Challenges for Policy and Practice Change," Chronic Poverty Research Centre/Overseas Development Institute Roundtable on Inheritance and the Intergenerational Transmission of Poverty, London 11 (2010), 6-17.

${ }^{53}$ Mikano E. Kiye, "The repugnancy and incompatibility tests and customary law in Anglophone Cameroon," African Studies Quarterly 15, no. 2 (2015): 85; E.A Taiwo, "Repugnancy clause and its Impact on Customary Law: comparing the South African and Nigerian Positions-some Lessons for Nigeria," Journal for Juridical Science 34, no. 1 (2009): 89-115; Liz Alden Wily, "The Status of Customary Land Rights in Africa Today," Rights to Resources in Crisis: Reviewing the Fate of Customary Tenure in Africa-Brief 4 (2012); 2-14; Lotsmart Fonjong, "Women's Land Rights and Working Conditions in Largescale Plantations in Sub-Saharan Africa," Africa Development 41, no. 3 (2016): 49-69. 
important reforms in the area of citizenship by ending gender discrimination in relation to the right of a woman to pass citizenship to her children or spouse, and that parties to a marriage have equal rights at the point of marriage, during the marriage and at the dissolution. ${ }^{54}$

In order to tackle violations of the rights of women and children in Kenya, the government has created a Ministry of Gender for Children and Social Development. A National Commission of Gender Development has been established in order to see to implementation on the National Policy on gender in the country. 'Gender officers' are also appointed in ministries and state corporations. The government has also set out a strategy to increase opportunities for women's participation in economic, social and political decision making through a specialized programme tagged as Vision 2030. The government also establishes a Women's Enterprise Fund to provide women access to financial services and enacted a Succession Act targeted at countering cultural attitudes promoting discriminations against women and the girl-child. ${ }^{55}$

This Act specially provides for the right of females to inherit property that was hitherto inaccessible under customary law. The government has also made efforts through the legislative process to fight violence against women through the promotion of a Family Protection Bill and a Sexual Offences Act; in addition to partnering with civil societies and community-based organizations to re-orientate citizens and change attitudes that encourage abuse of girl-child rights as well as

${ }^{54}$ Art. 45(3) of Child's Rights 1989; Norah Hashim Msuya, "Harmful Cultural and Traditional Practices: A Roadblock in the Implementation of the Convention on the Elimination of Discrimination Against Women and the Maputo Protocol on Women's Rights in Tanzania," (PhD diss., University of Central, 2017), 50-64; Michelo Hansungnle, "The African Charter on Human and Peoples Rights: A Critical Review," African Yearbook of International Law Online/AnnuaireAfricain De Droit International Online 8, no. 1 (2000): 265-331.

${ }^{55}$ M.G. Techane, p. 347-351; Elizabeth A. Oji, "Fighting Discrimination in Africa through CEDAW: Hard Fights-Easy Fights," New Eng. J. Int'l \& Comp. L. 16 (2010): 89; A. Andanje, " Efforts to Empower Women, Initiatives to Promote Sustainable Economic Growth Mutually Reinforcing," (A Report on Kenya General Assembly, 64, Third Committee, October 13, 2009), accessed May, 19, 2016, http://www.un.org/press/en/2009/gashc 3950.doc.htm. 
correct the inequalities between men and women. Female victims of violence are encouraged by the Ministry to seek legal recourse through a witness protection scheme where protection is provided for witnesses who fear reprisals.

In Kenya, some specialized non-governmental organizations promote campaigns to showcase and discourage violence against women and the girl-child. An example of such an organization is the Coalition on Violence Against Women - Kenya (COVAW-K), which is a registered, non-partisan and non-profit making national women's human rights non-governmental organization working to promote and advance women's human rights in a society free from all forms of violence against women. COVAW-K was established in 1995 as a result of a workshop organized by Women in Law and Development in Africa, (WILDAF) which sought to strengthen the networking capacities of women's organizations in Kenya. COVAW-K as an organized body sought to encourage victims of violence to speak out and report such acts of violations; be committed to breaking the silence concerning violence against women and girls in Kenyan communities, and work towards building capacities of individuals, communities and the entire nation to recognize violence against women as an abuse of human rights and also be encouraged to take appropriate measures to stop it by punishing perpetrators fittingly. Since its inception, COVAW-K has continued to be instrumental in labelling and treating violence against women as a crime and a human rights violation, whether perpetrated in private or in the public domain. Its overall aim is to reduce the incidence of violence against women and in cases where they occur to improve the management of violence against women.

Meanwhile, the African Network for the Prevention and Protection Against Child Abuse and Neglect (ANPPCAN) is an African childrights organization cutting across many countries in Africa and currently has chapters in 17 African countries. In Kenya, ANPPCAN is a charitable, non-profit organization registered as a non-governmental organization in 1995. It operates as a national resource centre on child abuse, child neglect and a promoter of children's rights. It provides information and technical expertise on child protection and child rights issues; carries out research on emerging children's issues; and when necessary lobbies governments, donors, other NGOs and communities on behalf of children. 
Aside from that, there is also the Legal Resources Foundation (LRF) which was established in 1994 as an autonomous project of the Kenyan Human Rights Commission was in the year 2000 registered as a trust and became an independent entity. Since then LRF has developed innovative methods to raise legal and human rights awareness among the young, underprivileged and undereducated classes in Kenya. Its programmes consist of community-based paralegal training, theatre for civic education, legal and human rights education for secondary schools, production of educational radio programmes and publication of materials to be used in its own and similar educational projects.

According to Otedo, ${ }^{56}$ the challenges to the application of girl-child rights in Kenya are varied but that the Kenyan government has put the following educational programmes in place to tackle girl-child education namely:

(i) Innovative Women Teachers (IWT) programme which is an empowerment programme for women teachers and the girl-child to build capacity of the teachers especially in ICT;

(ii) Partners in Learning (PIL);

(iii) Innovative Schools;

(iv) Innovative Students.

(v) To Young, the Constitution passed in 2010 provides powerful opportunities for women from minority and indigenous communities to capitalize on the new legal and political framework. ${ }^{57}$ It also goes

56 Kezia Waruguru Mbuthia, "Socio-Economic and Environmental Determinants to Household Food Security in Kyangwithya West Location, Kitui County, Kenya," (PhD diss., South Eastern Kenya University, 2018): 3952; Ferreira Rialize and Concellia Aoko Ondiek, "The Persistent Cultural Female Genital Mutilation Practice: A Cause for the Elusive Search For Access to Education of the Kenyan Girl Child," Commonwealth Youth And Development 10, No. 1 (2012): 60-73; Mwanahamisi G. Komora, "Challenges Facing the Education of the Girl Child In Kenya: A Case Study on Experiences and Views of Girls in Galole Constituency of Tana River County, Kenya," (Phd Diss., University of Nairobi, 2014): 64-73.

${ }^{57}$ R. Anita and V. K. Swamy, "Diversity Management at Workplace: Aspects, Challenges, and Strategies," International Journal of Engineering Technology Science and Research IJETSR5, no.1, (2018): 1-11; Solomon Kinyanjui, 
ahead to provide that all State organs and public officers have the duty to address the needs of vulnerable groups within the society including women, older members of the society etc.

\section{Similarities and Differences in the Chosen Countries.}

Angola has ratified a number of international conventions condemning FGM. Among these is the Convention on the Elimination of All Forms of Discrimination against Women (CEDAW), the UN Convention on the Rights of the Child (CRC), and the African Charter on the Rights and Welfare of the Child. The Maputo Protocol on the Rights of Women in Africa, a protocol to the African Charter on Human and People's Rights, which explicitly opposes FGM and other harmful practices such as giving out girl-children in marriage in exchange for bridewealth, has been signed but awaiting ratification. Reproductive health legislation that makes all forms of violence against women punishable by law, including FGM, has been on the books since 2002.

The national committee against harmful traditional practices has not been active in seeking an end to genital mutilation. Practically less has been done to ensure that the new laws, policies and institutions meet the requirements of the Convention. Hence, it is suggests that Angola and Mozambique learn from Kenya in order to record a positive impact on gender equality. In South Africa, apart from cases of FGM, child abduction, early marriage, the practice of torture and cruel, inhumane and degrading treatment (CIDT) remains a major human rights violation in post-apartheid. Despite the South African Constitution prohibiting torture and cruel, inhumane and degrading treatment, the country's ratification of the United Nations Convention Against Torture (UNCAT) and its signing of the Optional Protocol to the Convention Against Torture (OPCAT) and other international instruments outlawing

\footnotetext{
"Innovative Strategies for Managing Workforce Diversity in Kenyan Leading Corporations in Present Global Scenario," International Journal of Business and Management 8, no. 15 (2013): 20; Laia Bécares and Naomi Priest, "Understanding the Influence of Race/Ethnicity, Gender, and Class on Inequalities in Academic and Non-Academic Outcomes Among Eighth-Grade Students: Findings from An Intersectionality Approach," Plos One 10, no. 10 (2015).
} 
torture. $^{58}$ There is an urgent need to ratify Optional Protocol to the Convention against Torture in order to prevent torture and cruel, inhumane and degrading treatment and the establishment of correctional centres, police cells, psychiatric facilities, repatriation centres and places of safety for children and juvenile with regular visits. ${ }^{59}$

In Namibia, among the positive remarks the CRC made was the institution of an Ombudsman, which had the mandate to deal with complaints about human rights violations, including those relating to children. ${ }^{60}$ The community leaders were charged with responsibility particularly with respect to overcoming the negative influences of certain traditions and customs which has contributed to discrimination against the girl-child, children suffering from disabilities and children born out of wedlock. ${ }^{61}$ Numerous efforts have been made in terms of the law,

${ }^{58}$ Jensena et al., "Torture and Ill-treatment Under Perceived: Human Rights Documentation and the Poor," Human Rights Quarterly 39, no. 2 (2017): 393415; Jeevan Raj Sharma and Morten Koch Andersen, "Torture Redress Mechanisms in Nepal and Bangladesh," Economic \& Political Weekly 52, no. 17 (2017): 87; Jairo Rivas, "Official Victims' Registries: A Tool for the Recognition of Human Rights Violations," Journal of Human Rights Practice 8, no. 1 (2016): 116-127.

${ }^{59}$ Aptel Cécile, "The Protection of Children in Armed Conflicts," International Human Rights of Children (2019): 515-536; Lubabalo Ntsokolo and Nhlanhla Mlitwa, "Using Interactive ICT to Support the Rehabilitation of Juvenile ExConvicts in South Africa," (paper presented at the Proceedings of the 4th IDIA Conference, 2010): 1-18; L. Muntingh, Guide to the UN Convention Against Torture in South Africa, (Johannesburg: Centre for the Study of Violence and Reconciliation, 2011).

${ }^{60}$ Linda C. Reif, "The Transplantation and Adaptation: The Evolution of the Human Rights Ombudsman," BC Third World LJ 31 (2011): 269; Fiona Orr, "To What Extent is it Fair to Say that Children Are 'Vulnerable Victims' that Require Special Protection Under International Human Rights Law?" Journal of Social Welfare and Human Rights 2, no. 1 (2014): 87-105; Fiona Orr, "Do Children Require Special Protection under International Human Rights Law," King's Student L. Rev. 5 (2014): 43.

${ }^{61}$ Norah Hashim Msuya, "Tradition and Culture in Africa,"; John Cantius Mubangizi, "An African Perspective on Some Gender-Related Cultural Practices that Violate Human Rights and Perpetuate Women's Poverty," Journal of Social Sciences 47, no. 1 (2016): 68-78; Aborisade Olasunkanmi, "A Philosophical Appraisal of Basic Cultural Values in African 
policy reform, and child related initiatives and activities. It is expected that the situation with regard to compliance with the provisions of the CRC will improve considerably.

In order to address all aspects of trafficking in persons, the Namibia government had adopted the use of the Protocol to deal with trafficking in persons. Particular attention has been paid to women and children, to protect and assist the victims of such trafficking and to promote cooperation among States Parties in order to meet those objectives. The Child Care and Protection Bill is currently in the process of being finalized. This will address the issue of child trafficking. The envisaged Act makes child trafficking a criminal offence, and provides for extraterritorial jurisdiction to address trafficking by citizens or permanent residents of Namibia outside Namibia's borders.

Furthermore, the state has addressed this obligation by enacting the Prevention of Organised Crime Act as part of laws coming into force soon. It evident that among all the Southern Africa community states, only Kenya has put all machinery in motion to combat all forms of discriminatory practices challenging the equal participation of women and girl-child's rights. Hence this study advocates and suggests to other states to learn from Kenya as well.

\section{CONCLUSION}

From the preceding discussions, it is evident that issues of gender rights especially the rights of women and the girl-child in some States in the Southern African Developing states still remain muzzled by discriminatory customary practices. It is also trite that the relevant governments have taken legislative, judicial and executive steps to confront this perennial monster that keeps working against the liberty and freedom of women to the extent that they depersonalize and inhibit developmental efforts aimed towards enhancing women's rights. The achievement of women of their full potentials as human beings continue to be hampered by these discriminatory customary practices. The way

Tradition," International Journal of Politics and Good Governance 6, no. 2 (2015): 1-12; C. C. Asiwe and Odirin Omiegbe, "Legal and Ethical Issues of Persons with Special Needs in Nigeria," Educational Research and Reviews 9, no. 15 (2014): 516-522. 
out of this vicious circle can only be achieved through the instrumentality of the law and a shift in the developmental policies of the relevant governments.

It is true that most of the States of the SADC have ratified the CEDAW and the Convention on the Rights of the Child (CRC). Beyond ratification of relevant laws, these States should take all appropriate measures to implement the provisions of these laws as well as enact specific local legislation to outlaw these discriminatory practices that are antithetical to the protection of rights of women and the girl-child. Kenya has made tremendous constitutional efforts to fight gender imbalance and protect the human rights of women and the girl-child. However, the enforcement of these laws and the continuity of government policies remain a challenge to be surmounted. Increased advocacy and the creation of greater public awareness of rights by both the government and other agencies would entrench the better values of gender equality and the protection of human rights. Conclusively, there is no doubt that there is a need to give more attention to the implementation of the laws on discriminatory customary practices in these countries so as to save both the women and girl-child from the daily torture and harassment. They must be given their rights and positions in the society for a better society. Hence, the government of these countries should learn from their counterparts for effective implementation of the legal instruments that overcome discriminatory customary practices that goes against women's rights. 